\title{
PENGARUH PENGUNGKAPAN CORPORATE SOCIAL RESPONSIBILITY DAN GOOD CORPORATE GOVERNANCE TERHADAP PROFITABILITAS PERUSAHAAN INDEKS SRI KEHATI
}

\author{
Syahrul Effendi \\ Sekolah Tinggi Ilmu Ekonomi Indonesia \\ Arul.aikons@gmail.com
}

\begin{abstract}
The purpose of this study was to examine the effect of disclosure of Corporate Social Responsibility and Good Corporate Governance to the profitability of a company incorporated in sri kehati index in the Indonesia Stock Exchange in the period 2011-2015. This research is a correlation regression testing as an article describing the phenomenon in the form of the relationship between variables. The research data was obtained from annual reports and financial sites Indonesia Stock Exchange (BEI). Samples used as many as 14 companies qualified financial reports, sustainability reports listed in Indonesia Stock Exchange in 2011-2015. The sampling technique used literature. This study uses multiple regression analysis. Based on the analysis it can be concluded that the disclosure of Corporate Social Responsibility positive effect on NPM. Good Corporate Governance (Size commissioners) positive effect on ROE, ROA. Good Corporate Governance (Independent Commissioner) no positive effect on ROA and NPM. Good Corporate Governance (Audit Committee) positive effect on ROA and ROE.
\end{abstract}

Keywords: Corporate Social Responsibility, Good Corporate Governance, Board of commissioner size, Independent commissioner, Audit Committe, Profitability.

\section{PENDAHULUAN}

Kehadiran Yayasan Keanekaragaman Hayati Indonesia (KEHATI) sejak 12 Januari 1994 dimaksudkan untuk menghimpun dan mengelola sumberdaya yang selanjutnya disalurkan dalam bentuk dana hibah, fasilitasi, konsultasi dan berbagai fasilitas lain guna menunjang berbagai program pelestarian keanekaragaman hayati Indonesia dan pemanfaatannya secara adil dan berkelanjutan.Keberadaan Yayasan KEHATI tidak terlepas dari wujud pelaksanaan KTT Bumi di Rio de Janeiro tahun 1992 dan Deklarasi Tokyo tahun 1993 dimana pimpinan tiga negara yaitu Amerika Serikat, Jepang dan Indonesia sepakat bekerjasama untuk membantu program pelestarian keanekaragaman hayati secara berkelanjutan di Indonesia. Emil Salim, yang pada tahun 1993 telah selesai menjabat sebagai Menteri Negara Kependudukan dan Lingkungan Hidup, diminta oleh Pemerintah Indonesia untuk membentuk organisasi non-pemerintah sebagai penampung dan pelaksana program keanekaragaman hayati dengan bantuan hibah dari Pemerintah 
Amerika Serikat. Dengan bantuan rekan-rekan tokoh organisasi non-pemerintah, seperti Koesnadi Hardjasomantri, Ismid, Hadad, Erna Witoelar, M.S. Kismadi, dan Nono Anwar Makarim, disusunlah anggaran dasar, organisasi dan program kerja Yayasan Keanekaragaman Hayati Indonesia, disingkat KEHATI.

Corporate Social Responsibility (tanggung jawab sosial perusahaan) secara konseptual merupakan kepedulian perusahaan yang didasari triple bottom lines, yaitu profit (mencari laba), people (mensejahterakan orang) dan plannet (menjamin kelangsungan planet). CSR merupakan suatu bentuk kesungguhan perusahaan untuk menyisihkan sebagian harta kekayaan perusahaan guna mengurangi dampak negatif yang mungkin terjadi dan berupaya memaksimalkan dampak positif dari operasi perusahaan terhadap semua pihak yang berkepentingan dalam kegiatan ekonomi, sosial dan lingkungan. (Suharto, 2009). Dengan adanya pengungkapan CSR, itu akan membantu perusahaan dalam menyampaikan ke publik maupun investor bahwa selain ingin mendapatkan profit, perusahaan juga memperhatikan kondisi sosial dan lingkungan sekitar. Sarana pengungkap informasi sosial atau yang dikenal dengan laporan berkelanjutan (sustainability reporting) berguna untuk memberikan informasi kepada para investor tentang berbagai kegiatan sosial yang telah dilakukan perusahaan karena investor individual tertarik dengan informasi sosial yang dilaporkan dalam laporan tahunan. Perkembangan laporan keberlanjutan (sustainability reporting) di Indonesia cukup baik setelah ada ISRA (Indonesia Sustainability Reporting Award). Saat ini, di Indonesia, banyak perusahaan yang membuat laporan keberlanjutan dengan mengacu pada standar pelaporan yang dikeluarkan oleh the Global Reporting Initiative (GRI) bahkan mampu menduduki posisi tertinggi di kawasan ASEAN. Peningkatan pengungkapan CSR yang dilihat dari perkembangan laporan berkelanjutan diharapkan mampu meningkatkan citra perusahaan di mata masyarakat dan menarik investor untuk berinvestasi serta ikut berperan dalam meningkatkan pembangunan ekonomi.

Good Corporate Governance (GCG) merupakan suatu sistem, dan seperangkat peraturan yang mengatur hubungan antara berbagai pihak yang berkepentingan terutama dalam arti sempit hubungan antara pemegang saham dan dewan komisaris serta dewan direksi demi tercapainya tujuan korporasi. Komite Nasional Kebijakan Corporate Governance menyusun pedoman GCG untuk memudahkan para pelaku bisnis dalam menata dan mengarahkan semua pihak yang terlibat dalam kegiatan usaha. GCG diyakini memiliki banyak manfaat, jika diterapkan secara konsisten. Manfaat penerapan GCG antara lain: kinerja perusahaan terus membaik, harga saham dan citra perusahaan terus terdongkrak, kredibilitas perusahaan pun terus ikut naik melampaui batas-batas negara, baik di mata investor, mitra atau kreditor dan stakeholders lainnya. Meskipun penerapan GCG dapat memberikan keuntungan bagi perusahaan namun, penerapan GCG di Indonesia masih belum merata.

Profitabilitas merupakan kemampuan yang dicapai oleh perusahaan dalam satu periode tertentu. Dasar penilaian profitabilitas adalah laporan keuangan yang terdiri dari laporan neraca dan rugi-laba perusahaan. Penurunan profitabilitas menunjukkan suatu penurunan kinerja bagi perusahaan. Pada perode 2011-2015 secara umum nampak adanya penurunan profitabilitas dari perusahaan-perusahaan yang tergabung dalam SRI KEHATI. 
Permasalahan yang akan diteliti adalah 1)Apakah Corporate Social Responsility berpengaruh terhadap profitabilitas perusahaan yang terdaftar di BEI indeks Sri Kehati periode 2011-2015. 2) Apakah Good Corporate Governance (Ukuran Dewan Komisaris) berpengaruh terhadap profitabilitas perusahaan yang terdaftar di BEI indeks Sri Kehati periode 2011-2015. 3) Apakah Good Corporate Governance (Komisaris Independen)berpengaruh terhadap profitabilitas perusahaan yang terdaftar di BEI indeks Sri Kehati periode 2011-2015. 4) Apakah Good Corporate Governance (Komite Audit) berpengaruh terhadap profitabilitas perusahaan yang terdaftar di BEI indeks Sri Kehati periode 2011-2015.

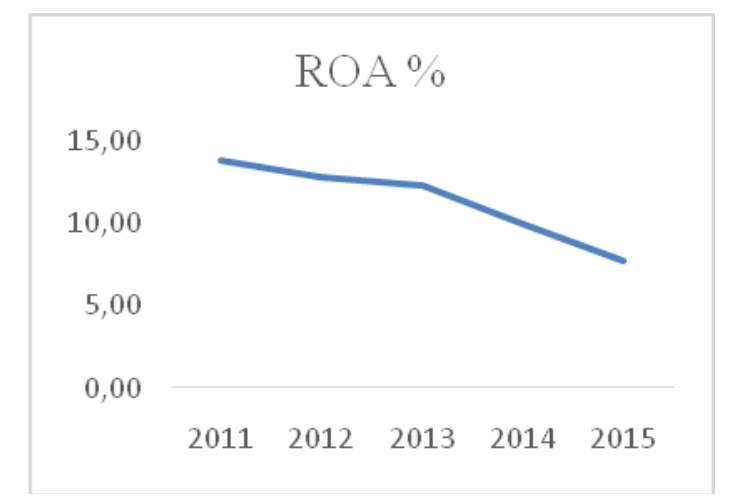

Gambar 1. Grafik Return of Assets

Penelitian ini bertujuan mencari bukti empiris pengaruh CSR dan corporate governance terhadap profitabiitas perusahaan yang tergabung dalam SRIKEHATI.

\section{KAJIAN TEORI}

Corporate Sosial Responsibility (CSR) merupakan suatu konsep akuntansi yang dapat membuat perusahaan terdorong untuk melaksanakan tanggung jawabnya terhadap lingkungan dan masyarakat. CSR timbul sebagai akibat dari kegiatan operasional perusahaan yang tidak hanya berdampak positif, tetapi juga mempunyai dampak negatif terutama bagi masyarakat dan lingkungan di sekitar perusahan.

CSR akan secara proaktif menaikkan ketertarikan publik dengan mendorong pertumbuhan dan perkembangan komunitas. Pada dasarnya, CSR merupakan suatu tindakan yang dilakukan oleh perusahaan dalam upaya untuk menaikkan ketertarikan public dengan memperhatikan tiga garis dasar (triple bottom line) : People, Planet,Profit. Selama ini belum ada satu teori tunggal yang diterima untukmenjelaskan akuntansi sosial dan lingkungan, sehingga masih banyak terdapat variasi dalam hal perspektif teoritis yang dapat diadopsi (Belkaoui dan Karpik, 1989).

OECD (The Organisation for Economic Co-operation and Development) mendefinisikan Corporate Governance sebagai sekumpulan hubungan antar pihak manajemen perusahaan, board, pemegang saham, dan pihak lain yang mempunyai kepentingan dengan perusahaan. Corporate Governance juga mensyaratkan adanya struktur perangkat untuk mencapai tujuan dan pengawasan atas kinerja. Corporate Governance yang baik dapat memberikan rangsangan bagi board dan manajemen untuk mencapai tujuan yang merupakan kepentingan perusahaan dan pemegang saham harus memfasilitasi pengawasan yang efektif sehingga 
mendorong perusahaan menggunakan sumber daya dengan lebih efisien (Surya dan Yustiavandana 2006).

Penerapan prinsip Corporate Governance ini adalah untuk menghasilkan kinerja perusahaan yang efektif dan efisien, melalui harmonisasi manajemen perusahaan. Dibutuhkan peran yang penuh komitmen dan independen dari dewan direksi dan dewan komisaris dalam menjalankan kegiatan perusahaan, sehingga menghasilkan profitabilitas yang baik.

Berdasarkan UU No. 40 Tahun 2007 tentang Perseroan Terbatas, dewan komisaris adalah organ perseroan yang bertugas melakukan pengawasan secara umum dan/atau khusus sesuai dengan anggaran dasar serta memberi nasihat kepada direksi. Kerangka tata kelola perusahaan harus memastikan pedoman strategis perusahaan, pemantauan yang efektif dari manajemen oleh dewan komisaris, dan akuntabilitas dewan komisaris untuk perusahaan dan para pemegang saham (OECD, 2004). Pengukuran dewan komisaris yang digunakan dalam penelitian ini menggunakan jumlah dewan komisaris yang ada dalam perusahaan (El-Chaarani, 2014).

Komisaris Independen. Komisaris independen adalah sebuah badan dalam perusahaan yang biasanya beranggotakan dewan komisaris yang independen yang berasal dari luar perusahaan yang berfungsi untuk menilai kinerja perusahaan secara luas dan keseluruhan. Komisaris independen merupakan pihak yang tidak terafiliasi dengan pemegang saham pengendali, anggota direksi dan dewan komisaris lain, dan perusahaan itu sendiri baik dalam bentuk hubungan bisnis maupun kekeluargaan (Wardhani, 2008).

Komite Audit. Komite audit bertugas untuk membantu dewan komisaris untuk memastikan bahwa laporan keuangan disajikan secara wajar sesuai dengan prinsip akuntansi yang berlaku umum, struktur pengendalian internal perusahaan dilaksanakan dengan baik, pelaksanaan audit internal dan eksternal dilaksanakan sesuai dengan standar audit yang berlaku, dan tindak lanjut temuan hasil audit dilaksanakan oleh manajemen (Wardhani, 2008).

Return on Asset (ROA). Penelitian ini menggunakan ROA untuk mengukur profitabilitas, dimana Return on Asset (ROA) adalah rasio yang digunakan untuk mengukur kemampuan manajemen perusahaan dalam memperoleh keuntungan dengan memanfaatkan keseluruhan total aset yang dimiliki (Attar, Islahuddin, \& Shabri, 2014). ROA mengukur seberapa efektif perusahaan dapat mengubah pendapatan dari pengembalian investasinya menjadi asset. Semakin tinggi ROA perusahaan, semakin baik. Menurut Dewi dan Widagdo (2012) ROA dapat dihitung dengan rumus:

$$
\text { Return on Asset }(\mathrm{ROA})=\frac{\text { Net Income }}{\text { Total Asset }}
$$

Return on Equity (ROE). Penelitian ini juga menggunakan Return on Equity (ROE) untuk mengukur profitabilitas karena apabila investor ingin melihat seberapa besar perusahaan menghasilkan return atas investasi yang mereka tanamkan, yang akan dilihat pertama kali adalah rasio profitabilitas, terutama ROE, karena rasio ini mengukur seberapa efektif perusahaan menghasilkan return bagi para investor. Return on Equity yang tinggi menunjukkan profitabilitas juga baik, yang mengakibatkan investor tertarik menanamkan modal. Sebaliknya, jika 
ROE yang rendah menunjukkan kondisi profitabilitas yang tidak baik, sehingga investor kurang tertarik untuk menanamkan modal pada perusahaan yang bersangkutan. Menurut Dewi dan Widagdo (2012) ROE diukur dari :

$$
\text { Return on Equity }(\mathrm{ROE})=\frac{\text { Net Income }}{\text { Total Equity }}
$$

Net Profin Margin (NPM). Net Profit Margin (NPM) adalah rasio yang digunakan untuk menunjukkan kemampuan perusahaan dalam menghasilkan keuntungan bersih. Menurut Bastian dan Suhardjono (2006), Net Profit Margin adalah perbandingan antara laba bersih dengan penjualan. Rasio ini sangat penting bagi manajer operasi karena mencerminkan strategi penetapan harga penjualan yang diterapkan perusahaan dan kemampuannya untuk mengendalikan beban usaha.

$$
\text { Net Profin Margin }(\mathrm{NPM})=\frac{\text { Net Income }}{\text { Total revenues }}
$$

\section{METODE PENELITIAN}

Penelitian ini menggunakan metode kuantitatif, yang menekankan analisis pada data numeric (angka) yang diolah dengan metode statistika. Metode kuantitatif adalah penelitian dengan memperoleh data yang berbentuk angka atau data kualitatif yang diangkakan. Desain penelitian ini kausalitas atau explanatory yaitu yang memberikan penjelasan secara konkrit tentang variabel yang merupakan penyebab dan variabel yang merupakan akibat.. Pada dasarnya, pendekatan kuantitatif dilakukan pada penelitian dalam rangka pengujian hipotesis dan mengambil kesimpulan hasilnya pada suatu probabilitas nihil. Dengan metode kuantitatif akan diperoleh signifikansi perbedaan kelompok atau signifikansi hubungan antar variabel yang diteliti.

Tabel 1. Sampel Penelitian

\begin{tabular}{lll}
\hline No & Kriteria & Jumlah \\
\hline 1 & $\begin{array}{l}\text { Perusahaan yang masuk tergabung dalam } \\
\text { indeks sri kehati pada tahun 2011-2015 }\end{array}$ & 25 \\
2 & $\begin{array}{l}\text { Perusahaan yang tidak konsisten kedalam } \\
\text { indeks sri kehati pada tahun 2011-2015 }\end{array}$ & 6 \\
3 & $\begin{array}{l}\text { Tidak memiliki data yang lengkap terkait } \\
\text { variabel atau pelaporannya }\end{array}$ & 5 \\
\hline & Total sampel yang dapat digunakan & 14 \\
\hline
\end{tabular}

Objek penelitian adalah seluruh perusahaan yang tergabung dalam INDEKS SRIKEHATI. Populasi penelitian adalah 25 perusahaan, Jumlah perusahaan yang memenuhi kriteria sampel adalah sejumlah 14 perusahaan yang masuk ke dalam indeks sri kehati secara konsisten yang terdaftar di Bursa Efek Indonesia untuk periode tahun 2011 sampai dengan tahun 2015. Pemilihan sampel dalam penelitian ini ditentukan dengan menggunakan metode purposive. Pengambilan sampel penelitian ini digambarkan pada table di bawah ini: 
Tabel 2. Pengukuran Variabel penelitian

\begin{tabular}{|c|c|c|}
\hline No & Variabel Penelitian & Pengukuran \\
\hline \multirow[t]{4}{*}{1} & CSR & \multirow{4}{*}{$\mathrm{CSR}=\frac{N}{K}$} \\
\hline & penelitian oleh Juniati dan Ratna (2014) & \\
\hline & N=Jumlah Pengungkapan Perusahaan & \\
\hline & K=Jumlah Item Pengungkapan GRI 4 (91) & \\
\hline 2 & $\begin{array}{l}\text { Ukuran Dewan Komisaris } \\
\text { penelitian oleh Matsila dan Merianto (2013) }\end{array}$ & Jumlah Seluruh UDK \\
\hline 3 & Komisaris Independen & \multirow[t]{2}{*}{ Jumlah komisaris independen } \\
\hline & Penelitian oleh Ramlan (2015) & \\
\hline 4 & Komite Audit & \multirow{3}{*}{ Jumlah seluruh komite audit } \\
\hline & Penelitian oleh Muntiah (2013) & \\
\hline 5 & Return of Asset & \\
\hline \multirow{3}{*}{6} & Penelitian oleh Yaparto dan Frisko (2015) & \multirow{2}{*}{$\begin{aligned} & \mathrm{ROA}= \frac{\text { LabaBersih }}{\text { Total Asset }} \\
& \text { LabaBersih }\end{aligned}$} \\
\hline & Return of Equity & \\
\hline & Penelitian muntiah (2014) & \multirow{2}{*}{$\begin{array}{r}\mathrm{ROE}=\overline{\text { Total Ekuitas }} \\
\text { Net Income }\end{array}$} \\
\hline \multirow[t]{2}{*}{7} & Net Profit Margin & \\
\hline & & $\mathrm{NPM}=$ Total revenues \\
\hline
\end{tabular}

Jenis data yang digunakan dalam penelitian ini menggunakan data sekunder. Sumber data untuk RoA, RoE dan NPM diambil dari Laporan kinerja tercatat website www.idx.co.id. Untuk data Good Corporate Governance seperti Ukuran Dewan Komisaris, Komisaris Independen dan Komite Audit didapat dari laporan keuangan tahunan dan terampir di halaman lampiran.

Untuk sumber data GRI 4 diambil dari website masing-masing perusahaan jika pengungkapan GRI tidak tercantum di dalam laporan keuangan tahunan.

Teknik Pengumpulan data pada penelitian ini menggunakan metode kepustakaan yaitu (mengkopi, mendownload, mencatat, menghitung).

Adapun Kriteria sampel yang digunakan:

a. Perusahaan yang masuk pada 14 perusahaan yang tergabung di indeks sri kehati konsisten dari tahun 2011-2015.

b. Menerbitkan annual report lengkap, Suistainable Reporting, dan data tentang Corporate Governance khususnya memuat informasi tentang ukuran dewan direksi, komisaris independen, dan komite audit.

c. Memiliki data yang lengkap terkait dengan variabel - variabel yang digunakan dalam penelitian.

\subsection{Teknik Analisis Data}

Analisis statistik deskriptif digunakan untuk memberikan deskripsi atas variabel-variabel penelitian secara statistik. Statistik deskriptif yang digunakan dalam penelitian ini adalah nilai rata-rata (mean), maksimum, minimum, dan standar deviasi. 
Statistik digunakan untuk mengambil keputusan permasalahan penelitian ini adalah pencarian pengaruh variable bebas kepada variable terikat dengan pendekatan regresi. Pendekatan regresi memerlukan persyaratan memenuhi asumsi klasik.

\section{HASIL DAN PEMBAHASAN}

Pengujian statistik deskriptif berguna sebagai alat untuk menganalisis data tanpa maksud membuat sebuah kesimpulan dengan cara menggambarkan sampel yang telah ada. Statistik deskriptif memberikan gambaran atau deskripsi suatu data yang dilihat dari nilai rata-rata (mean), standar deviasi, minimum, maksimum dan varian (Ghozali, 2011).

Tabel 3. Statistik Deskriptif

\begin{tabular}{lllll}
\hline & Min & Max & Mean & Std Dev \\
\hline CSR & 0.1 & 0.98 & 0.4437 & 0.22447 \\
UDK & 5 & 11 & 6.6 & 1.498 \\
KI & 2 & 5 & 2.91 & 0.847 \\
KA & 3 & 7 & 3.89 & 1.043 \\
ROA & 1.31 & 71.51 & 12.29 & 12.0394 \\
ROE & 5.95 & 125.81 & 27.6961 & 27.2492 \\
NPM & 5.33 & 44.03 & 20.8466 & 9.66161 \\
\hline
\end{tabular}

Dari hasil pengujian statistic deskriptif di atas, dapat diketahui bahwa:

a. Corporate Social Responsibility

Dari hasil pengujian statistik deskriptif menjelaskan bahwa perusahaan yang sedikit melaksanakan sesuai dengan ketentuan GRI adalah 10\% yaitu perusahaan PT. Semen Gresik Tbk, dan yang paling banyak adalah 98\% yaitu PT. Timah Tbk, Rata-rata CSR yang melaksanakan sesuai dengan ketentuan Pedoman GRI sebesar 44\%.

b. Ukuran Dewan Komisaris (UDK)

Data Statistik ini menunjukan bahwa rata-rata perusahaan sampel memiliki jumlah anggota Dewan Komisaris sebanyak 7 orang dengan jumlah anggota dewan paling sedikit 5 orang yang dimiliki oleh PT. Bank Central Asia Tbk, dan jumlah terbanyak adalah 11 orang yang dimiliki oleh PT. Astra International Tbk

c. Komisaris Independen (KI)

Data statistik ini menunjukkan bahwa rata-rata perusahaan sampel memiliki Komisaris Independen sebanyak 3 orang, jumlah Komisaris Independen paling sedikit adalah 2 orang yang dimiliki PT. Jasa Marga Tbk, dan jumlah Komisaris Independen yang paling banyak dimiliki PT. Bank Rakyat Indonesia, Tbk dan PT. Astra International Tbk yaitu sebanyak 5 orang.

d. Komite Audit (KA)

Data Statistik ini menunjukan bahwa rata-rata perusahaan sampel memiliki jumlah Komite Audit sebanyak 4 orang, jumlah komite audit paling banyak dimiliki oleh PT. Perusahaan Gas Negara Tbk sebanyak 7 orang, dan jumlah komite audit paling sedikit 3 orang yang dimiliki oleh PT. Astra Agro Lestari Tbk. 
e. Return on Assets (ROA)

Dari hasil pengujian statistic deskriptif, Rata-rata Return on Assets (ROA) sebesar 12,29 yang artinya setiap 100 Rupiah aset perusahaan akan menghasilkan laba sebesar 12.29, dimana nilai minimum ROA sebesar 1,31 yang dimiliki oleh PT. Bank Danamon, nilai maksimum ROA sebesar 71,51 dimiliki oleh PT. Unilever Indonesia Tbk.

f. Return on Equity (ROE)

Dari hasil pengujian statistic deskriptif, Rata-rata Return on Equity (ROE) sebesar 27,69 yang artinya setiap 100 Rupiah ekuitas pemegang saham perusahaan akan menghasilkan laba senilai 27.69, dimana nilai minimum ROE sebesar 5,95 yang dimiliki oleh PT. Astra Agro Lestari Tbk. nilai maksimum ROE sebesar 125,81 yang dimiliki oleh PT. Unilever Indonesia Tbk.

g. Net Profit Margin (NPM)

Dari hasil pengujian statistic deskriptif, Rata-rata Net Profit Margin (NPM) sebesar 20,85 yang artinya setiap 100 rupiah sales akan menghasilkan laba 20.85, dimana nilai minimum sebesar 5,33 yang dimiliki oleh PT. Astra Agro Lestari Tbk, nilai maksimum sebesar 44,03 yang dimiliki oleh PT. Bank Central Asia.

Uji normalitas bertujuan untuk menguji apakah dalam model regresi, variabel dependen dan variabel independen memiliki distribusi data yang normal atau tidak. Dalam penelitian ini digunakan cara untuk melakukan uji normalitas data uji Kolmogrorov-Smirnov Z (I-sample K-S).Berdasarkan hasil uji One Sample Kolmogorov-Smirnov dapat diketahui bahwa nilai Asymp.Sig.(2-tailed) sebesar $0,220>$ tingkat signifikansi 0,05 yang artinya data berdistribusi secara normal.

Uji multikolinearitas bertujuan untuk menguji apakah model regresi ditemukan adanya korelasi antara variabel bebas (independen). Model regresi yang baik seharusnya tidak terjadi korelasi diantara variabel independen. Berdasarkan hasil pengolahan data didapatkan nilai variance inflation faktor (VIF) dan nilai tolerance yang disajikan pada Tabel di bawah ini:

Tabel 4. Uji Multikolinearitas

\begin{tabular}{llll}
\hline Variabel & Tolerance & VIF & Kesimpulan \\
\hline CSR & 0.93 & 1.076 & Tidak terjadi multikolinearitas \\
UDK & 0.748 & 1.337 & Tidak terjadi multikolinearitas \\
KI & 0.759 & 1.319 & Tidak terjadi multikolinearitas \\
KA & 0.893 & 1.132 & Tidak terjadi multikolinearitas \\
\hline
\end{tabular}

Berdasarkan tabel di atas didapatkan nilai VIF persamaan untuk mengukur pengaruh Corporate Social Responsibility, Ukuran Dewan Komisaris, Komisaris Independen, Komite Audit terhadap profitabilitasdapat dilihat bahwa seluruh variabel memiliki nilai tolerance lebih besar dari 0,1 dan nilai VIF lebih kecil dari 10. Maka dapat disimpulkan bahwa tidak terjadi multikolinearitas dalam penelitian ini. Data tersebut baik untuk digunakan dalam model regresi.

Tujuan dari uji autokorelasi ini adalah untuk mengetahui ada tidaknya penyimpangan asumsi klasik autokorelasi. Uji run test adalah bagian dari statistic 
non parametric yang dapat digunakan untuk menguji apakah antar residual terdapat korelasi yang tinggi atau tidak. Jika antar residual tidak terdapat hubungan korelasi maka dikatakan bahwa residual adalah acak atau random. Berdasarkan hasil run test untuk variable RoA, RoE \& NPM sebesar 0.864 sehingga dapat dikatakan bahwa tidak ada autokorelasi dalam data ini karena sig.(2-tailed) lebih besar daripada 0.05.

Uji Heteroskedastisitas digunakan untuk mengetahui ada tidaknya penyimpangan asumsi klasik heteroskedastisitas, yaitu adanya ketidaksamaan varian dari residual untuk semua pengamatan pada model regresi. Persyaratan yang harus terpenuhi dalam model regresi adalah tidak adanya gejala heteroskedastisitas.

Tabel 5. Hasil Uji Heteroskedastisitas

\begin{tabular}{llll}
\hline \multirow{2}{*}{ Variabel } & \multicolumn{3}{l}{ Sig.(2-tailed) } \\
\cline { 2 - 4 } & RoA & RoE & NPM \\
\hline CSR & 0.303 & 0.798 & 0.597 \\
UDK & 0.854 & 0.506 & 0.906 \\
KI & 0.302 & 0.742 & 0.145 \\
KA & 0.469 & 0.886 & 0.346 \\
\hline
\end{tabular}

Dari tabel 5 hasil uji heterokedastisitas di atas terlihat bahwa nilai tstatistik dari seluruh variabel (Corporate Social Responsibility, Ukuran Dewan Komisaris, Komisaris Independen, Komite Audit) tidak ada yang signifikan secara statistik, semua memiliki nilai signifikansi berada di atas 0,05 (p-value >0,05), sehingga dapat disimpulkan bahwa model regresi yang digunakan dalam penelitian ini tidak mengalami masalah heteroskedastisitas, dengan kata lain model regresi yang digunakan terhindar dari masalah heteroskedastisitas

Uji serentak dilakukan untuk mengetahui berapa besar pengaruh dari variabel independen terhadap variabel dependen. Dalam penelitian ini uji regresi dilakukan untuk mengetahui berapa besar pengaruh Corporate Social Responsibility, Ukuran Dewan Komisaris, Komisaris Independen, Komite Audit terhadap profitabilitas ROA, ROE dan NPM. Berikut ini disajikan tabel persamaan regresi untuk uji serentak (Uji-F).

Tabel 6. Hasil Pengujian Pengaruh CSR dan GCG Terhadap ROA Indeks Sri Kehati Periode 2011-2015

\begin{tabular}{llll}
\hline Variabel & Koefisien Regresi & t & Sig. \\
\hline Constant & 22.535 & 2.749 & 0.01 \\
CSR & 9.269 & 1.478 & 0.14 \\
UDK & -3.225 & -3.08 & 0 \\
KI & 3.587 & 1.949 & 0.06 \\
KA & 1.384 & -0.66 & 0.51 \\
R $^{2}$ & 0.174 & & \\
Fhitung & & 3.421 & 0.013 \\
\hline
\end{tabular}

Penjelasan persamaan regresi ROA (1) sebagai berikut: 
a. Nilai koefisien regresi untuk konstanta sebesar 22.535 dengan signifikansi pada 0.01 (<0.05). Artinya jika Corporate Social Responsibility, Ukuran Dewan Komisaris, Komisaris Independen, Komite Audit tidak ada, maka setiap 100 rupiah asset sudah menghasilkan profitabilitas (ROA) sebesar 22.535

b. $\quad$ Nilai koefisien regresi (b) Corporate Social Responsibility sebesar 9.269 dengan nilai signifikan 0.14 lebih besar dari 0.05 artinya terdapat pengaruh CSR yang positif tetapi tidak signifikan.

c. Nilai koefisien regresi (b) Ukuran Dewan Komisaris sebesar -3.225 signifikansi 0.000 lebih kecil dari 0.05 berarti bahwa Ukuran Dewan Komisaris meningkat sebesar 1 orang, maka akan menyebabkan penurunan atau pengurangan nilai profitabilitas (ROA) sebesar -3.225.

d. Nilai koefisien regresi (b) Komisaris Independen sebesar 3.587 signifikansi 0.06 lebih besar dari 0.05 berarti bahwa kenaikan Komisaris Independen sebesar 1 orang, maka akan menyebabkan KI yang positif tidak signifikan.

e. Nilai koefisien regresi (b) Komite Audit sebesar 1.384 signifikansi 0.51 lebih besar dari 0.05 berarti bahwa kenaikan Komite Audit sebesar 1 orang, maka akan menyebabkan KA yang positif tidak signifikan.

Berdasarkan Tabel 6 persamaan regresi linear yang secara matematis diformulasikan sebagai berikut:

$$
\text { ROA }=22.535+9.269 \mathrm{CSR}-3.225 \mathrm{UDK}+3.587 \mathrm{KI}+1.384 \mathrm{KA}
$$

Dari hasil uji ANOVA (F-test) ROA dapat dilihat bahwa nilai Fhitung didapatkan sebesar 3.421 dan memiliki nilai sig 0,013. Dari daftar F Table, nilai F Table dengan taraf signfikansi 0,05 dengan jumlah variabel independen $=4$, variabel dependen $=3$, dan sampel 70 didapatkan nilai $F$ Table sebesar 2,50. Berarti bahwa Nilai Fhitung lebih besar dari pada Ftabel $(3.421>2,50)$. Dengan nilai Sig 0,013 lebih kecil dari 0,05. Maka dapat disimpulkan bahwa Ho ditolak dan $\mathrm{Ha}$ diterima pada taraf signifikansi 0,05. Kesimpulannya adalah bahwa variabel independen secara bersama-sama mempunyai pengaruh yang signifikan terhadap variabel dependen, yaitu Return on Asset (ROA).

Tabel 7. Hasil Pengujian Regresi CSR dan GCG Terhadap ROE Indeks Sri Kehati Periode 2011-2015

\begin{tabular}{llll}
\hline Variabel & Koefisien Regresi & t & Sig. \\
\hline Constant & 48.418 & 2.964 & 0.004 \\
CSR & 5.204 & 0.416 & 0.678 \\
UDK & -9.887 & -4.74 & 0 \\
KI & 17.924 & 4.886 & 0 \\
KA & -2.577 & -0.93 & 0.354 \\
$\mathrm{R}^{2}$ & 0.360 & & \\
Fhitung & & 9.122 & 0.00 \\
\hline
\end{tabular}

$\mathrm{ROE}=48.818+5.204 \mathrm{CSR}-9.887 \mathrm{UDK}+17.924 \mathrm{KI}-2.577 \mathrm{KA}$

Penjelasan persamaan regresi ROE (2) sebagai berikut: 
a. Konstanta sebesar 48.418 berarti bahwa jika Corporate Social Responsibility, Ukuran Dewan Komisaris, Komisaris Independen, Komite Audit tidak ada, maka setiap 100 rupiah ekuitas sudah menghasilkan profitabilitas (ROE) sebesar 48.418 signifikansi pada 0.004 lebih kecil dari 0.05 .

b. Nilai koefisien regresi (b) Corporate Social Responsibility sebesar 5.204 signifikansi 0.678 lebih besar dari 0.05 artinya CSR yang positif tidak signifikan.

c. Nilai koefisien regresi (b) Ukuran Dewan Komisaris sebesar -9,887 signifikansi 0.000 lebih kecil daripada 0.05 berarti bahwa Ukuran Dewan Komisaris sebesar 1 orang, maka akan menyebabkan penurunan dan pengurangan nilai variabel profitabilitas (ROE) sebesar -9.887.

d. Nilai koefisien regresi (b) Komisaris Independen sebesar 17.924 signifikansi 0.000 lebih kecil dari 0.05 berarti bahwa Komisaris Independen sebesar 1 orang, maka akan menyebabkan KI positif tidak signifikan.

e. $\quad$ Nilai koefisien regresi (b) Komite Audit sebesar -2.577 signifikansi 0.354 lebih besar daripada 0.05 berarti bahwa Komite Audit sebesar 1 orang, maka akan menyebabkan penurunan nilai profitabilitas (ROE) sebesar 2.577 .

Dari hasil uji ANOVA (F-test) ROE pada dapat dilihat bahwa nilai Fhitung didapatkan sebesar 9.122 dan memiliki nilai sig 0,000. Dari daftar F Table, nilai $\mathrm{F}$ Table dengan taraf signfikansi 0,05 dengan jumlah variabel independen $=4$, variabel dependen $=3$, dan sampel 70 didapatkan nilai $\mathrm{F}$ Table sebesar 2,50. Berarti bahwa Nilai Fhitung lebih besar dari pada Ftabel (9,122 > 2,50). Dengan nilai Sig 0,000 lebih kecil dari 0,05. Maka dapat disimpulkan bahwa Ho ditolak dan Ha diterima pada taraf signifikansi 0,05. Kesimpulannya adalah bahwa variabel independen secara bersama-sama mempunyai pengaruh yang signifikan terhadap variabel dependen, yaitu Return on Asset (ROE).

Tabel 8. Hasil Pengujian Regresi CSR dan GCG Terhadap NPM Indeks Sri Kehati Periode 2011-2015

\begin{tabular}{llll}
\hline Variabel & Koefisien Regresi & t & Sig. \\
\hline Constant & 26.659 & 3.909 & 0 \\
CSR & -11.964 & -2.29 & 0.025 \\
UDK & -1.615 & -1.85 & 0.069 \\
KI & 1.717 & 1.122 & 0.266 \\
KA & 1.325 & 1.15 & 0.254 \\
R $^{2}$ & 0.112 & & \\
Fhitung & & 2.052 & 0.097 \\
\hline
\end{tabular}

Persamaan regresi yag dihasilkan adalah NPM $=$ 26.659 - 11.964CSR 1.615UDK + 1.717KI + 1.325KA 
Penjelasan persamaan regresi NPM (3) sebagai berikut:

a. Konstanta sebesar 26.659 berarti bahwa jika Corporate Social Responsibility, Ukuran Dewan Komisaris, Komisaris Independen, Komite Audit tidak ada, maka setiap 100 rupiah sales sudah menghasilkan profitabilitas (NPM) sebesar 26.659 signifikansi pada nilai 0.000 lebih kecil daripada 0.05 .

b. Nilai koefisien regresi (b) Corporate Social Responsibility sebesar -11.694 nilai signifikansi 0.025 lebih kecil dari 0.05 berarti bahwa kenaikan Corporate Social Responsibility sebesar 1 satuan, maka akan menghasilkan penurunan dan pengurangan nilai variabel profitabilitas (NPM) sebesar -11.694.

c. Nilai koefisien regresi (b) Ukuran Dewan Komisaris sebesar -1.615 nilai signifikansi 0.069 lebih besar dari 0.05 berarti bahwa Ukuran Dewan Komisaris sebesar 1 orang, maka akan menyebabkan penurunan dan pengurangan nilai variabel profitabilitas (NPM) sebesar -1.615.

d. Nilai koefisien regresi (b) Komisaris Independen sebesar 1.717 signifikansi 0.266 lebih besar dari 0.05 berarti bahwa Komisaris Independen sebesar 1 satuan, maka KI yang positif tidak signifikan.

e. Nilai koefisien regresi (b) Komite Audit sebesar 1.325 signifikansi 0.254 lebih besar dari 0.05 berarti bahwa Komite Audit sebesar 1 orang, maka akan menyebabkan KA positif tidak signifikan.

Dari hasil uji ANOVA (F-test) NPM pada tabel di atas dapat dilihat bahwa nilai Fhitung didapatkan sebesar 2.052 dan memiliki nilai sig 0,097. Dari daftar F Table, nilai $F$ Table dengan taraf signfikansi 0,05 dengan jumlah variabel independen $=4$, variabel dependen $=3$, dan sampel 70 didapatkan nilai $\mathrm{F}$ Table sebesar 2,50. Berarti bahwa Nilai Fhitung lebih kecil dari pada Ftabel (2.052 < 2,50). Dengan nilai Sig 0,097 lebih besar dari 0,05. Maka dapat disimpulkan bahwa Ho diterima dan Ha ditolak pada taraf signifikansi 0,05. Kesimpulannya adalah bahwa variabel independen secara bersama-sama tidak mempunyai pengaruh yang signifikan terhadap variabel dependen, yaitu net profit margin (NPM).

Dalam penelitian ini uji t dilakukan pada persamaan regresi yang menjelaskan pengaruh Corporate Social Responsibility, Ukuran Dewan Komisaris, Komisaris Independen, Komite Audit terhadap ROA, ROE dan NPM disajikan pada tabel berikut ini.

\subsection{Pengaruh Corporate Social Responsibility terhadap profitabilitas Perusahaan (Return on Asset)}

Berdasarkan hasil pengujian hipotesis, diperoleh hasil bahwa Pengungkapan Corporate Social Responsibility berpengaruh positif tidak signifikan terhadap profitabilitas (Return on Asset). Dengan pengungkapan Corporate Social Responsibility yang semakin luas akan memberikan dampak yang positif tetapi tidak signifikan terhadap profitabilitas. Hasil penelitian ini sesuai dengan penelitian yang dilakukan oleh Yaparto dan Frisko (2013) yang menyatakan pengungkapan CSR berpengaruh positif tidak signifikan terhadap profitabilitas yang diproksikan dengan ROA. Waddock \& Graves (1997) 
berasumsi bahwa perusahaan dengan perilaku yang bertanggung jawab mungkin memiliki kelemahan kompetitif, karena mereka memiliki biaya yang tidak perlu. Biaya ini, berada langsung pada bottom line dan tentu akan mengurangi keuntungan pemegang saham dan kekayaan. Hal inilah yang menyebabkan laba perusahaan menurun dan akan diikuti dengan peningkatan ROA yang tidak signifikan. Tetapi hasil penelitian ini tidak sejalan dengan penelitian yang dilakukan oleh Nelling dan Webb (2006) bahwa Corporate Social Responsibility berpengaruh negatif dan signifikan terhadap ROA.

\subsection{Pengaruh Corporate Social Responsibility terhadap Profitabilitas (Return on Equity)}

Berdasarkan hasil pengujian hipotesis, diperoleh hasil bahwa Pengungkapan Corporate Social Responsibility berpengaruh positif tidak signifikan terhadap profitabilitas (Return on Equity). Hasil penelitian ini sejalan dengan hasil penelitian yang dilakukan oleh Hana (2010) yang menunjukan bahwa CSR berpengaruh positif terhadap ROE. Selain itu, kebanyakan investor memiliki persepsi yang rendah terhadap pengungkapan CSR hanya sebagai bagian dari promosi atau iklan dan menghindari untuk memberikan informasi yang lebih terperinci dan relevan. Oleh karena itu, tidak jarang perusahaan akan mengungkapkan hal-hal yang menurut perusahaan tidak memberikan keuntungan bagi perusahaan pada laporan tahunan sehingga memicu kualitas pengungkapan CSR masih dipertimbangkan oleh investor sehingga mengurangi ketertaikan investor untuk menanamkan modal kepada perusahaan sehingga menyebabkan peningkatan ROE perusahaan secara tidak signifikan. Tetapi Hasil penelitian ini berbeda dengan penelitian yang dilakukan Yaparto dan Frisko (2013) yang menyatakan bahwa tingkat pengungkapan CSR dalam laporan tahunan perusahaan berpengaruh negatif tidak signifikan terhadap ROE.

\subsection{Pengaruh Corporate Social Responsibility terhadap Profitabilitas (Net Profit Margin)}

Berdasarkan hasil pengujian hipotesis, diperoleh hasil bahwa Pengungkapan Corporate Social Responsibility berpengaruh negatif signifikan terhadap profitabilitas (Net Profit Margin). Hal ini dapat diintrepretasikan bahwa semakin tinggi indeks pengungkapan CSR yang dilakukan perusahaan, berpengaruh secara signifikan pada peningkatan net profit margin (NPM) yang diperoleh perusahaan. Dengan perusahaan melaksanakan CSR maka akan meningkatkan biaya yang tinggi sehingga mengakibatkan NPM menurun. Hasil penelitian ini sejalan dengan penelitian yang dilakukan Candrayanthi dan Saputra (2013) yang menyatakan adanya hubungan yang kuat antara pengungkapan CSR terhadap NPM. .Sementara Hasil penelitian ini tidak sejalan dengan hasil penelitian yang dilakukan oleh Priyanka (2013) bahwa Pengungkapan Corporate Social Responsibility berpengaruh positif terhadap Net Profit Margin.

\subsection{Pengaruh Ukuran Dewan Komisaris terhadap Profitabilitas (Return of Assets)}

Berdasarkan hasil pengujian hipotesis, diperoleh hasil bahwa Ukuran Dewan Komisaris berpengaruh negatif terhadap profitabilitas (Return on Asset). Hasil 
penelitian ini sejalan dengan penelitian yang dilakukan oleh Matsila dan Wahyu (2013), Al-Amameh (2014) dan Jacking \& Johl (2009) yang menyatakan Ukuran dewan komisaris berpengaruh negatif signifikan terhadap profitabilitas

Penelitian ini tidak sejalan yang dilakukan Tertius dan Christiawan (2015) dan Ridho (2013) yang menyatakan bahwa Ukuran Dewan Komisaris berpengaruh positif terhadap profitabilitas (ROA). Hal tersebut dikarenakan dengan makin banyaknya anggota dewan komisaris maka badan ini akan mengalami kesulitan dalam menjalankan perannya, diantaranya kesulitan dalam komunikasi dan koordinasi antar anggota dewan komisaris. Hal ini berarti jumlah dewan komisaris tidak berpengaruh terhadap ROA. Hal ini terjadi diduga karena pada sektor keuangan, banyak pihak-pihak luar yang mengawasi profitabilitas sektor keuangan dan regulasi yang ditetapkan agar perusahaan sektor keuangan memiliki profitabilitas tetap baik sehingga besar atau kecil jumlah dewan komisaris tidak mempengaruhi ROA.

\subsection{Pengaruh Ukuran Dewan Komisaris Profitabilitas (Return of Equity)}

Berdasarkan hasil pengujian hipotesis, diperoleh hasil bahwa Ukuran Dewan Komisaris berpengaruh negatif signifikan terhadap profitabilitas (Return on Equity). Penelitian ini sesuai dengan penelitian yang dilakukan oleh Matsila dan Wahyu (2013) yang menyatakan Ukuran dewan komisaris independen berpengaruh negatif signifikan terhadap profitabilitas. Penelitian tidak sejalan dengan penelitian yang dilakukan oleh Muntiah (2013) Pengangkatan dewan komisaris oleh perusahaan mungkin hanya dilakukan untuk pemenuhan regulasi saja tapi belum mampu menegakkan GCG di dalam perusahaan. Semakin banyak personil yang menjadi dewan komisaris dapat berakibat pada makin buruk profitabilitas yang dimiliki perusahaan. Hal tersebut dikarenakan dengan semakin banyaknya anggota dewan komisaris maka badan ini akan mengalami kesulitan dalam menjalankan perannya, diantaranya kesulitan dalam komunikasi dan koordinasi antar anggota dewan komisaris. Hal inilah yang dipandang buruk bagi sebagian besar investor yang terefleksi dalam profitabilitas (ROE).

\subsection{Pengaruh Ukuran Dewan Komisaris terhadap Profitabilitas (Net Profit Margin)}

Berdasarkan hasil pengujian hipotesis, diperoleh hasil bahwa Ukuran dewan komisaris berpengaruh negative signifikan terhadap profitabilitas perusahaan (Net Profit Margin). Hasil penelitian ini sejalan dengan hasil penelitian yang dilakukan oleh Istighfarin (2015) yang menyatakan bahwa Ukuran dewan komisaris berpengaruh negatif signifikan terhadap Net profit margin. Penelitian ini juga sejalan dengan Penelitian Hardikasari (2011) menyebutkan bahwa ukuran dewan komisaris memiliki pengaruh negative terhadap Net profit margin. semakin banyak personil yang menjadi dewan komisaris dapat berakibat pada makin buruk profitabilitas yang dimiliki perusahaan. Pengawasan yang dilakukan oleh dewan komisaris dalam jumlah besar atau kecil menghasilkan kualitas pengawasan yang sama. Selain itu dikarenakan jumlah komisaris yang terlalu banyak cenderung mengakibatkan proses pengambilan keputusan berjalan lebih lamban karena harus meminta pendapat semua komisaris. Keputusan menjadi tidak fleksibel. Ketidakefektifan pengambilan keputusan tersebut 
berdampak pada ketidakmaksimalan perusahaan dalam memanfaatkan peluang bisnis yang ada secara langsung (Puspitasari dan Ernawati, 2010). Hasil penelitian ini tidak sejalan dengan Utami (2011) yang menyatakan bahwa ukuran dewan komisaris memiliki pengaruh positif signifikan terhadap Net profit margin.

\subsection{Pengaruh Komisaris Independen Profitabilitas (Return of Asset)}

Berdasarkan hasil pengujian hipotesis, diperoleh hasil bahwa Komisaris Independen berpengaruh positif signifikan terhadap Profitabilitas Perusahaan (Return on Asset). Hasil penelitian ini sejalan dengan penelitian yang dilakukan oleh Al-Shahafi (2015). Penelitian ini tidak sejalan dengan penelitian yang dilakukan oleh Kardjaya dan Sisdyani (2014) yang menemukan bahwa komisaris independen berpengaruh negatif terhadap ROA.

\subsection{Pengaruh Komisaris Independen Profitabilitas (Return of Equity)}

Berdasarkan hasil pengujian hipotesis, diperoleh hasil bahwa Komisaris Independen berpengaruh positif signifikan terhadap profitabilitas (Return on Equity). Hasil ini konsisten dengan hasil penelitian yang dilakukan oleh Muntiah (2013) yang menyatakan Komisaris independen memiliki pengaruh positif signifikan terhadap profitabilitas (ROE), semakin besar jumlah komisaris independen maka keputusan yang dibuat dewan komisaris lebih mengutamakan kepada kepentingan perusahaan.

Penelitian ini tidak sejalan Novrianti et.al (2012). Hal ini menunjukkan bahwa independensi Dewan Komisaris tidak memberikan kontribusi pada peningkatan profitabilitas. Selain itu, keberadaan komisaris independen dalam perusahaan hanyalah bersifat formalitas untuk memenuhi regulasi saja. Oleh karena itu, meskipun tingkat independensi dalam dewan komisaris sudah tinggi, tetap saja tidak akan mempengaruhi profitabilitas perusahaan agar semakin baik, tetapi malah justru menurunkan profitabilitas.

\subsection{Pengaruh Komisaris Independen terhadap Profitabilitas (Net Profit Margin)}

Berdasarkan hasil pengujian hipotesis, diperoleh hasil bahwa Pengungkapan komisaris independen berpengaruh positif signifikan terhadap profitabilitas (Net Profit Margin). Hasil penelitian ini sejalan dengan Utami (2011) sedangkan hasil penelitian ini tidak sejalan dengan hasil penelitian yang dilakukan oleh Sam'ani (2008) yang menyatakan bahwa komisaris independen tidak berpengaruh positif terhadap Net Profit Margin, Hal ini menunjukkan bahwa independensi Dewan Komisaris tidak memberikan kontribusi pada peningkatan profitabilitas, dan keberadaan komisaris independen dalam perusahaan hanyalah bersifat formalitas untuk memenuhi regulasi saja.

\subsection{Pengaruh Komite Audit Profitabilitas (Return of Assets)}

Berdasarkan hasil pengujian hipotesis, diperoleh hasil bahwa Komite Audit berpengaruh positif tidak signifikan terhadap profitabilitas (Return on Asset). Hasil penelitian sejalan dengan Utami (2011) yang menyatakan Semakin banyak komposisi komite audit maka profitabilitas akan terawasi dengan baik 
sehingga profitabilitas akan meningkat. Komite audit ditempatkan sebagai mekanisme pengawasan antara manajemen dengan pihak eksternal, sehingga komite audit dipandang dapat meningkatkan profitabilitas melalui pengawasan tersebut. Penelitian Xie et al. (2003) juga menyatakan bahwa ukuran komite audit dapat meningkatkan efektivitas komite audit sehingga mampu mencegah tindakan manajemen laba dan meningkatkan profitabilitas. Hal ini tidak sejalan dengan penelitian Widyati (2013) bahwa KA berpengaruh negatif terhadap ROA.

\subsection{Pengaruh Komite Audit terhadap Profitabilitas (Return of Equity)}

Berdasarkan hasil pengujian hipotesis, diperoleh hasil bahwa Komite Audit berpengaruh negative tidak signifikan terhadap profitabilitas (Return on Equity). Penelitian ini sesuai dengan penelitian yang dilakukan oleh Novrianti et.al (2013). Hasil penelitian ini tidak sesuai dengan hasil penelitian yang dilakukan oleh Muntiah (2013) dari hasil penelitian tersebut menyatakan bahwa komite audit berpengaruh positif terhadap profitabilitas. Komite audit ditempatkan sebagai mekanisme pengawasan antara manajemen dengan pihak eksternal, sehingga komite audit dipandang dapat meningkatkan profitabilitas melalui pengawasan tersebut. Sehingga para stakeholder terutama investor akan semakin percaya atas profitabilitas.

\subsection{Pengaruh Komite Audit terhadap Profitabilitas (Net Profit Margin)}

Berdasarkan hasil pengujian hipotesis, diperoleh hasil bahwa Pengungkapan komite audit berpengaruh positif signifikan terhadap profitabilitas (Net Profit Margin). Hasil penelitian ini sejalan dengan hasil penelitian yang dilakukan oleh Utami (2011). Hasil penelitian ini tidak sejalan dengan Kemalasari (2009) menyatakan bahwa komite audit berpengaruh negatif terhadap profitabilitas perusahaan.

\section{PENUTUP}

Penelitian ini bertujuan untuk mengetahui pengaruh Corporate Social Responsibility, Ukuran Dewan Komisaris, Komisaris Independen, dan Komite Audit terhadap Profitabilitas (ROA, ROE dan NPM) pada perusahaan yang tergabung dalam indeks sri kehati yang terdaftar di Bursa Efek Indonesia selama periode 2011-2015. Berdasarkan hasil dari analisis dan pembahasan pada bab sebelumnya, maka dapat disimpulkan bahwa :

1. Pengungkapan Corporate Social Responsibility signifikan negatif terhadap Net Profit Margin. Pengungkapan Corporate Social Responsibility tidak signifikan positif terhadap Return on Assets dan Return on Equity.

2. Pada penelitian ini, Ukuran dewan komisarissignifikan negatif terhadap Return on Assets dan Return on Equity. Pengungkapan Ukuran dewan komisaris tidak signifikan negatif terhadap Net Profit Margin.

3. Komisaris Independenterdapat signifikan yang positif terhadap Return on Equity. Komisaris Independentidak signifikan yang positif terhadap Return on Assets dan Net Profit Margin.

4. Komite Audit tidak signifikan yang positif baik terhadap Return on Assets, dan NPM sedangkan terhadap Return on Equity tidak signifikan negatif. 
Mengacu hasil Penelitian ini beberapa saran yang diajukan adalah: 1) jika manajemen perusahaan ingin profitabilitas tinggi maka kelola dengan baik ukuran dewan komisaris serta komisaris independennya karena investor akan memperhatikan; 2) jika Investor ingin mendapatkan perusahaan dengan profitabilitas tinggi maka semakin banyak komisaris independen di dalam suatu perusahaan maka profitabilitasnya tinggi, 3) Pemerintah sebagai regualtor hendaknya mengatur agar penerapan CSR dan GCG dijadikan mandatory sehingga perusahaan-perusahaan benar-benar dapat melakukan sustainability report yang baik mengikuti table pengungkapan GRI 4, dan 4) untuk Peneliti Selanjutnya beberapa saran adalah: (a) penelitian berikutnya agar tidak perlu lagi meneliti CSR pada perusahaan yang tergabung dalam indeks sri kehati dan menambahkan variabel kebijkan investasi, capital structure dan kebijakan dividen; (b) dapat meneliti untuk menemukan berapa jumlah orang untuk ukuran dewan komisaris, komisaris independen dan komite audit yang optimal dalam perusahaan, dan (c) penelitian selanjutnya dapat meneliti variabel seperti akuntabilitas, transparansi dan responsibility.

\section{DAFTAR PUSTAK}

Al-Amameh, A. (2014). "Corporate Governance, Ownership Structure and Bank Performance in Jordan". International Journal of Economics and Finance, 6(6), 69-81.

Al-Shahafi, Ashraf and Lisa Barnes. 2015. Does Corporate Governance Affect Financial Performance In The Banking Sector? Evidence From Saudi

Arabia. International Journal of Economics. Vol 3 Issue 3 pg 1-26. March. University Of Newcastle. Australia

Attar, D., Islahuddin, and Shabri, M. (2014). "Pengaruh Penerapan Manajemen Risiko terhadap Kinerja Keuangan Perbankan yang Terdaftar di Bursa Efek Indonesia". Jurnal Akuntansi, 3(1), 10-20.

Belkaoui, A. and PG. Karpik, 1989. "Determinants of the Corporate Decision to Disclose Social Information". Acoounting, Auditing and Accountability Journal, Volume. 2, Nomor 1, hal. 36-51.

Budiartha, Ketut. 2008. “Cara Pandang Undang-Undang RI No. 40 Tahun 2007 dan Undang-Undang RI No. 17 Tahun 2000 Terhadap Corporate Social Responsibility (CSR)". Diakses dari

website:http://ejournal.unud.ac.id/abstrak/budiartha.pdf, 28 Oktober 2016

Candrayanthi, A.A. dan I.D.G Dharma Saputra. 2013. "Pengaruh Pengungkapan CSR Terhadap Kinerja Keuangan (Studi Empiris Perusahaan Pertambangan)". E-Jurnal Akuntansi. Vol 4 No.1 Hal 141158. Fakultas Ekonomi .Universitas Udayana, Bali.

Dewi, R. K., dan Widagdo, B. (2012). "Pengaruh Corporate Social Responsibility Dan Good Corporate Governance Terhadap Kinerja Perusahaan". Jurnal Manajemen Bisnis Vol. 2 No. 01 Hal 81-97. Edisi April 
El-Chaarani, H. .2014. The Impact of Corporate Governance on the Performance of Lebanese Banks. The International Journal of Business and Finance Research, 8(5), 22-34.

Hana, Zera Restavia Finandra. 2013. "Pengaruh Pengungkapan Corporate Social

Responsibility terhadap kinerja keuangan perusahaan telekomunikasi yang terdaftar di Bursa Efek Indonesia”. Jurnal Akuntansi. Hal 1-14.Fakultas Ekonomi dan Bisnis. Universitas Brawijaya

Istigfharin D dan Wirawati, Ni Gusti Putu. 2015. Pengaruh GCG Terhadap profitabilitas pada BUMN. Jurnal Akuntansi. Vol 11 No 2 Mei. Halaman 564-581. Denpasar.Bali.

Jacking, B., and Johl, S. 2009. Board Structure and Firm Performance: Evidence from India's Top Companies. Corporate Governance: an International Review, 14(4), 492-509. Retrieved from http://dro.deakin.edu.au/view/DU:30022719 diakses 28 Oktober 2016

Juniati, Ratna. 2014. "Pengaruh pengungkapan Good Corporate Governance dan Corporate Social Responsibility terhadap kinerja perusahaan perbankan”. E-journal Magister Akuntansi Trisakti. Vol.1, No.2, September 2014: 181-198.

Karjaya, I Wayan dan Eka Sisdyani. 2014. Pengaruh Tingkat Pengungkapan CSR dan Mekanisme GCG pada Kinerja Keuangan Perusahaan Pertambangan. E-Jurnal Akuntansi. Vol 8.3 Hal 620-629. Universitas Udayana. Bali

Kemalasari, Endang. 2009. Pengaruh Penerapan Good Corporate Governance Terhadap Kinerja Perusahaan Perbankan Yang Terdaftar Di Bursa Efek Indonesia. Tesis. Sekolah Pascasarjana Fakultas Ekonomi. Universitas Sumatera Utara.Medan.

Matsila, Ika Wahyu Merianto. 2013. Skripsi. Pengaruh Corporate Governance terhadap kinerja keuangan perusahaan. Jurusan Akuntansi Fakultas Ekonomika dan Bisnis. Universitas Diponegoro. Semarang

Muntiah, Siti 2013. Pengaruh Mekanisme Corporate Governance terhadap kinerja perusahaan. Jurnal Akuntansi. Vol 5 No.2 Hal 1-17 Mei.

Nelling, Edward and Elizabeth Webb. 2006. CSR dan Financial Performance : The Virtous Circle Revisited. Finance E-Journal. Vol.1 No.2 Pg 65-82

Novrianti, Vesy dan Riadi Armas. 2012. “ Pengaruh CSR dan GCG terhadap Kinerja Perusahaan (Studi Pada Perusahaan Manufaktur Periode 20092011)". Jurnal Ekonomi, Fakultas Ekonomi. Universitas Riau.

OECD. 2004. The OECD Principles of Corporate Governance. France: Organization for Economic Co-operation and Development (OECD) Publications Service.

Permanasari, Mirra. 2010. Pengaruh Penerapan Corporate Social Responsibility Terhadap Tingkat Profitabilitas, Besaran Pajak Penghasilan, Dan Biaya Operasi Pada Perusahaan Yang Terdaftar Di Bursa Efek Indonesia. Jurnal akuntansi vol 12 pp 1-14

Priyanka, Felyna. 2013. Pengaruh Pengungkapan CSR terhadap profitabilitas pada perusahaan highprofile yang terdaftar di BEI 2009-2011. Yogyakarta. 
Puspitasari, Filia dan Endang Ernawati. 2010. "Pengaruh Mekanisme Corporate Governance terhadap Kinerja Keuangan Badan Usaha". Jurnal Manajemen Teori dan Terapan, Tahun 3, No. 2, Agustus 2010

Ramlan, Dandes dan Popi. 2015. "Pengaruh Sistem Good Corporate Governance Terhadap Kinerja Keuangan Perusahaan”. Jurnal Akuntasi. Vol 6 No.1 Hal 1-14. Jurusan Akuntansi, Fakultas Ekonomi, Universitas Bung Hatta. Sam'ani. 2008. Pengaruh Good Corporate Governance dan Leverage terhadap Kinerja Keuangan pada Perbankan yang Terdaftar di BEI Tahun 20042007. E-Jurnal. Vol 2 No 1 Hal 334-341. Semarang: Universitas Diponegoro.

Suharto, Edi. 2009. Membangun Masyarakat Memberdayakan Rakyat Kajian Strategis Pembangunan Kesejahteraan Sosial. Bandung; rafika ADITAMA

Surya, Indra dan Ivan Yustiavandana, 2006. Penerapan Good Corporet Governance Mengesampingkan Hak-hak Istimewa Demi Kelangsungan Uasaha. Jakarta: kencana.

Tertius, Melia, dan Yulius Christiawan. 2015. "Pengaruh Good Corporate Governance terhadap Kinerja Perusahaan pada Sektor Keuangan". Bussiness Accounting Review Vol 3 No. 1 Hal 223-232. Universitas Kristen Petra.Semarang.

Utami, Nurina. 2011. "Pengaruh Good Corporate Governance Terhadap Kinerja Keuangan Pada Perusahaan Yang Terdaftar Di Corporate Governance Perception Index". Jurnal Akuntansi. Vol 4 No.1 Hal 1-11. Fakultas Ekonomi, Universitas Gunadarma.Jakarta.

Waddock, Sandra A \& Samuel B. Graves.1997. The Corporate Social Performance-Financial Performance Link. Strategic Management Journal.18 (4). Page 303-319.

Wardhani, Diah Kusuma (2008). "Pengaruh Corporate Governance Terhadap Kinerja Perusahaan di Indonesia"Skripsi. Fakultas Ekonomi. Universitas Islam Indonesia. Yogyakarta.

Wati, Like Monisa. 2012. "Pengaruh Praktek Good Corporate Governance Terhadap Kinerja Keuangan Perusahaan Bursa Efek Indonesia". Jurnal Manajemen. Vol 1 No.1 Hal 1-7 . September. Prodi Manajemen Fakultas Ekonomi. Universitas Negeri Padang

Widyati, Maria Francisca. "Pengaruh Dewan Direksi, Komisaris Independen, Komite Audit, Kepemilikan Manajerial dan Kepemilikian Institutional terhadap Kinerja Keuangan". Jurnal Manajemen. Vol 1 No 1 Hal 234239. Januari 2013. Jurusan Manajemen, Fakultas Ekonomi. Universitas Negeri Surabaya.

Xie, B., W.N. Davidson, dan P.J. DaDalt. 2003. "Earnings Management and Corporate Governance: The Role of Board and The Audit Committee". Journal of Corporate Finance, 9, 295 - 316.

Yaparto, Marissa, dan Dianne Frisko. 2013. "Pengaruh Corporate Social Responsibility terhadap kinerja keuangan pada sektor manufaktur yang terdaftar di Bursa Efek Indonesia pada periode 2010-2011”. Jurnal ilmiah. Vol.2 No.1. Hal 1-19. Universitas Surabaya 